\title{
Współautorstwo publikacji w wybranych polskich i zagranicznych czasopismach z zakresu bibliologii i informatologii
}

\author{
Jacek Tomaszczyk \\ Instytut Bibliotekoznawstwa i Informacji Naukowej \\ Uniwersytet Śląski
}

\begin{abstract}
Abstrakt
Cel/teza: Celem artykułu jest przedstawienie wyników badań współautorstwa publikacji z zakresu bibliologii i informatologii, przeprowadzonych na podstawie wybranych czasopismach polskich i zagranicznych, opublikowanych w latach 2000-2009. Autor dodatkowo prezentuje wyniki analizy wykorzystania anglojęzycznych czasopism przez polskich bibliologów i informatologów, uznając cytowania obcojęzycznych publikacji za jeden ze wskaźników kompetencji językowych, niezbędnych do podejmowania międzynarodowej współpracy naukowej.

Koncepcja/metody badań: Badania przeprowadzono na podstawie danych zgromadzonych w bazie CYTBIN oraz pięciu czasopism zagranicznych: International Journal of Information Management, Journal of Academic Librarianship, Journal of Documentation, Journal of the American Society for Information Science and Technology oraz Library and Information Science Research.

Wyniki i wnioski: Przeprowadzone badania ukazały tendencję wzrostu liczby publikacji wieloautorskich w piśmiennictwie zagranicznym w latach 2000-2009, w których artykuły wieloautorskie stanowią 39\% ogółu publikacji. Natomiast w literaturze polskiej zaobserwowano w tym okresie stały, $9 \%$ udział publikacji wieloautorskich. W badanych czasopismach zagranicznych regularnie pojawiają się artykuły trzech i większej liczby autorów, stanowiąc $16 \%$ ogółu publikacji, podczas gdy w czasopismach polskich publikowane są artykuły autorstwa, co najwyżej trzech osób, stanowiąc zaledwie $1 \%$ wszystkich publikacji.

Oryginalność/wartość poznawcza: Przeprowadzone badanie przedstawia w kategoriach ilościowych współautorstwo publikacji w polskich czasopismach z zakresu bibliologii i informatologii i porównuje je z publikacjami w czasopismach zagranicznych.
\end{abstract}

\section{Słowa kluczowe}

Badania bibliometryczne. Bibliologia i informatologia. Polska. Współautorstwo. Współpraca międzynarodowa.

Otrzymany: 2.02.2014. Poprawiony: 2.04.2014. Zaakceptowany: 10.04.2014.

\section{Wstęp}

Współpraca i komunikacja leżą u podstaw rozwoju człowieka, który dzięki umiejętności działania w grupie i posługiwania się językiem osiągnął sukces ewolucyjny i wysoki poziom cywilizacji.

W działalności naukowej współpraca przyjmuje różne formy. Naukowcy wymieniają doświadczenia i dzielą się wiedzą podczas konferencji, warsztatów, staży i gościnnych wykładów, w prywatnej korespondencji i publicznych dyskusjach na forach internetowych, 
w nieformalnych rozmowach kuluarowych i podczas sformalizowanej współpracy przy realizacji dużych projektów badawczych. Jednak najbardziej widoczną i możliwą do badania w kategoriach ilościowych jest współpraca, której efektem są wspólne publikacje naukowe.

Od XVII w. do lat 20. XX w. obowiązywała reguła: jedna publikacja - jeden autor (Greene, 2007). W latach 1920-1950 coraz częściej łamano tę zasadę, a prawdziwy przełom nastąpił w latach 80. XX w., zgodnie z prognozami, jakie przedstawił Derek J. de Solla Price w 1963 r. w książce pt. Little Science, Big Science. Zwracał on uwagę na wzrost współpracy naukowej i współautorstwa publikacji w XX w. i przewidywał, że do 1980 r. znikną artykuły pisane przez pojedynczych autorów, a wciąż rosnąca współpraca będzie owocować publikacjami pisanymi wspólnie przez wielu badaczy (Price, 1963, 87-89). Od ukazania się książki Price'a w kolejnych dekadach prowadzono wiele badań bibiometrycznych, które potwierdzały wzrost liczby artykułów pisanych przez więcej niż jednego autora w różnych dziedzinach nauki (zob. Harsanyi, 1993), przy czym tempo zmian było zależne od dziedziny (O'Connor, 1970). Mott Greene na przykładzie tygodnika Nature zauważa, iż od lat 50. XX w. niemal każdy numer czasopisma ma podobną liczbę artykułów, ale obecnie aż czterokrotnie większą liczbę autorów. Autorstwo jednoosobowe praktycznie przestało istnieć, a w niektórych dziedzinach, np.w genetyce, klimatologii czy fizyce cząstek elementarnych, zaczęły regularnie pojawiać się publikacje mające ponad stu autorów (Greene, 2007).

Głównym celem artykułu jest ukazanie współpracy wśród bibliologów i informatologów w Polsce i za granicą, na podstawie analizy współautorstwa artykułów opublikowanych w wybranych polskich i zagranicznych czasopismach naukowych w latach 2000-2009. Celem dodatkowym jest zbadanie wykorzystania czasopism anglojęzycznych przez polskich bibliologów i informatologów. Znajomość języka angielskiego jest podstawą współpracy międzynarodowej, a jednym ze wskaźników kompetencji językowych może być liczba anglojęzycznej literatury cytowanej w publikacjach.

\section{Metodologia}

Badaniem objęto wybrane polskie oraz zagraniczne czasopisma z zakresu bibliologii i informatologii, opublikowane w latach 2000-2009. Analizę publikacji polskich przeprowadzono na podstawie danych zgromadzonych w bazie CYTBIN ${ }^{1}$. Do badania wybrano czasopisma, których artykuły, opublikowane w latach 2000-2009, zostały zarejestrowane w bazie. Są to:

(1) Bibliotekarz ${ }^{2}$

(2) Praktyka i Teoria Informacji Naukowej i Technicznej (PTINT),

(3) Przeglad Biblioteczny,

${ }^{1}$ CYTBIN, dostępny pod adresem http://www1.bg.us.edu.pl/bazy/cytbin, jest bibliograficzną bazą danych, gromadzącą opisy bibliograficzne wraz z informacją o publikacjach cytowanych, zamieszczanych w bibliografiach załącznikowych i/lub w przypisach bibliograficznych. CYTBIN rejestruje opisy bibliograficzne dokumentów (artykułów i recenzji) pochodzących z najważniejszych czasopism z zakresu bibliologii i informatologii, m.in. Bibliotekarza, Praktyki $i$ Teorii Informacji Naukowej $i$ Technicznej, Przegladu Bibliotecznego, Roczników Bibliotecznych, Zagadnień Informacji Naukowej. Do badania wybrano cztery czasopisma, ponieważ tylko dla nich w bazie zarejestrowano dane za lata 2000-2009.

${ }^{2}$ W bazie brakuje opisów artykułów dla tego tytułu za rok 2005. 
(4) Zagadnienia Informacji Naukowej (ZIN).

Analizę czasopism zagranicznych wykonano na podstawie informacji pochodzących z bazy Web of Science. Do badania wybrano czasopisma:

(1) International Journal of Information Management,

(2) Journal of Academic Librarianship,

(3) Journal of Documentation,

(4) Journal of the American Society for Information Science and Technology

(5) Library and Information Science Research.

Wybrane czasopisma zagraniczne należą do grupy periodyków reprezentujących szerokie spektrum zagadnień z zakresu bibliologii i informatologii i zostały uznane za podstawę wymiany doświadczeń naukowych w tej dyscyplinie (Drabek, 2007).

Celem badania było uzyskanie informacji na temat liczby artykułów sygnowanych nazwiskiem jednego lub więcej autorów, aby wskazać tendencję we współautorstwie publikacji w ciągu dziesięciu lat objętych badaniem (lata 2000-2009).

\section{Wyniki badań - czasopisma polskie}

Wśród 1322 artykułów opublikowanych w badanych czasopismach polskich, 91\% stanowią publikacje jednoautorskie, $8 \%$ publikacje dwuautorskie, a pozostały $1 \%$ posiada trzech autorów. Tabela 1 prezentuje liczbę artykułów w badanych czasopismach z podziałem na publikacje 1, 2, i 3-autorskie. Najwięcej publikacji wieloautorskich znalazło się w czasopiśmie Praktyka i Teoria Informacji Naukowej i Technicznej (43), a najmniej w Zagadnieniach Informacji Naukowej (8).

Tabela 1. Liczba artykułów w badanych czasopismach

\begin{tabular}{|l|c|c|c|}
\hline \multirow{2}{*}{\multicolumn{1}{c|}{ Czasopismo }} & \multicolumn{3}{c|}{ Liczba autorów } \\
\cline { 2 - 4 } & $\mathbf{1}$ & $\mathbf{2}$ & $\mathbf{3}$ \\
\hline Bibliotekarz & 435 & 37 & 3 \\
\hline Przegląd Biblioteczny & 376 & 29 & 3 \\
\hline PTINT & 195 & 36 & 7 \\
\hline ZIN & 193 & 6 & 2 \\
\hline
\end{tabular}

Wśród publikacji dwuautorskich autorzy $27 \%$ artykułów wywodzą się z różnych instytucji, natomiast wśród publikacji z trzema autorami 16\% artykułów zostało napisanych przez autorów z dwóch instytucji, a 11\% z trzech. Stąd wniosek, iż współautorstwo w ponad 70\% wynika ze współpracy między autorami tej samej instytucji.

Poszukując tendencji zmian liczebności współautorstwa posłużono się średnią liczbą autorów, przypadającą na jedną publikację w poszczególnych latach. Wyniki obliczeń prezentuje tabela 2, w której zgromadzone dane pozwalają zauważyć, że w badanych czasopismach w ciągu dziesięciu lat, średnia liczba autorów na artykuł niewiele się zmienia i że nie istnieje żadna tendencja rosnąca lub malejąca.

\footnotetext{
${ }^{3}$ Obecnie czasopismo nosi tytuł Journal of the Association for Information Science and Technology.
} 
Tabela 2. Średnia liczba autorów na jedną publikację w latach 2000-2009

\begin{tabular}{|l|c|c|c|c|c|c|c|c|c|c|c|}
\hline Czasopismo & 2000 & 2001 & 2002 & 2003 & 2004 & 2005 & 2006 & 2007 & 2008 & 2009 & $\begin{array}{c}\text { Śr. } \\
2000- \\
2009\end{array}$ \\
\hline Bibliotekarz & 1.10 & 1.08 & 1.17 & 1.08 & 1.08 & b.d. & 1.06 & 1.06 & 1.08 & 1.10 & 1.09 \\
\hline $\begin{array}{l}\text { Przegląd } \\
\text { Biblioteczny }\end{array}$ & 1.03 & 1.07 & 1.11 & 1.00 & 1.12 & 1.09 & 1.06 & 1.16 & 1.09 & 1.07 & 1.08 \\
\hline PTINT & 1.23 & 1.45 & 1.29 & 1.27 & 1.09 & 1.09 & 1.10 & 1.00 & 1.08 & 1.19 & 1.18 \\
\hline ZIN & 1.04 & 1.00 & 1.00 & 1.00 & 1.13 & 1.15 & 1.00 & 1.17 & 1.05 & 1.06 & 1.06 \\
\hline Średnia & 1.10 & 1.16 & 1.14 & 1.08 & 1.10 & 1.10 & 1.06 & 1.11 & 1.08 & 1.11 & 1.10 \\
\hline
\end{tabular}

Biorąc za wskaźnik współautorstwo publikacji w czasopismach można wyciągnąć wniosek, iż w dziedzinie bibliologii i informatologii naukowcy w Polsce zdecydowanie preferują indywidualny tryb pracy, a preferencja ta w latach 2000-2009 była na zbliżonym poziomie. Tworząc wspólne artykuły, autorzy w zdecydowanej większości (ponad 70\%) ograniczają się do współpracy z osobami z tej samej instytucji.

\section{Wyniki badań - czasopisma zagraniczne}

Wśród 4685 artykułów opublikowanych w badanych czasopismach zagranicznych z zakresu bibliologii i informatologii 61\% stanowią publikacje jednoautorskie, 23\% - dwuautorskie, $10 \%$ publikacji posiada trzech autorów, a pozostałe $6 \%$ to publikacje sygnowane więcej niż trzema nazwiskami autorów.

Tabela 3. Współautorstwo publikacji w badanych czasopismach zagranicznych

\begin{tabular}{|c|c|c|}
\hline Liczba autorów & Liczba publikacji & \% \\
\hline 1 & 2835 & 60.51 \\
\hline 2 & 1062 & 22.67 \\
\hline 3 & 487 & 10.39 \\
\hline 4 & 177 & 3.78 \\
\hline 5 & 73 & 1.56 \\
\hline 6 & 30 & 0.64 \\
\hline 7 & 11 & 0.23 \\
\hline 8 & 2 & 0.04 \\
\hline 9 & 4 & 0.09 \\
\hline 10 & 1 & 0.02 \\
\hline 11 & 2 & 0.04 \\
\hline 15 & 1 & 0.02 \\
\hline
\end{tabular}

Tabele 4-8 przedstawiają współautorstwo publikacji w każdym z badanych czasopism w latach 2000-2009. 
Wspótautorstwo publikacji w wybranych... | Co-authorship of Publications in Selected...

Tabela 4. Współautorstwo publikacji w czasopiśmie International Journal of Information Management

\begin{tabular}{|c|c|c|c|c|c|c|c|c|c|c|}
\hline \multirow{2}{*}{$\begin{array}{c}\text { Liczba } \\
\text { autorów }\end{array}$} & \multicolumn{10}{|c|}{ Liczba publikacji } \\
\cline { 2 - 14 } & $\mathbf{2 0 0 0}$ & $\mathbf{2 0 0 1}$ & $\mathbf{2 0 0 2}$ & $\mathbf{2 0 0 3}$ & $\mathbf{2 0 0 4}$ & $\mathbf{2 0 0 5}$ & $\mathbf{2 0 0 6}$ & $\mathbf{2 0 0 7}$ & $\mathbf{2 0 0 8}$ & $\mathbf{2 0 0 9}$ \\
\hline 1 & 32 & 27 & 10 & 26 & 32 & 24 & 26 & 33 & 34 & 40 \\
\hline 2 & 17 & 11 & 17 & 13 & 10 & 16 & 15 & 13 & 24 & 15 \\
\hline 3 & 4 & 5 & 4 & 8 & 11 & 6 & 11 & 9 & 14 & 15 \\
\hline 4 & 2 & 2 & 2 & 4 & 2 & 1 & 2 & 1 & 3 & 4 \\
\hline 5 & 1 & 0 & 0 & 0 & 0 & 1 & 0 & 0 & 1 & 1 \\
\hline 6 & 0 & 0 & 0 & 0 & 0 & 1 & 1 & 0 & 1 & 1 \\
\hline 11 & 0 & 0 & 0 & 0 & 0 & 1 & 0 & 0 & 0 & 0 \\
\hline
\end{tabular}

Tabela 5. Współautorstwo publikacji w czasopiśmie Journal of Academic Librarianship

\begin{tabular}{|c|c|c|c|c|c|c|c|c|c|c|}
\hline \multirow{2}{*}{$\begin{array}{c}\text { Liczba } \\
\text { autorów }\end{array}$} & \multicolumn{10}{|c|}{ Liczba publikacji } \\
\cline { 2 - 14 } & $\mathbf{2 0 0 0}$ & $\mathbf{2 0 0 1}$ & $\mathbf{2 0 0 2}$ & $\mathbf{2 0 0 3}$ & $\mathbf{2 0 0 4}$ & $\mathbf{2 0 0 5}$ & $\mathbf{2 0 0 6}$ & $\mathbf{2 0 0 7}$ & $\mathbf{2 0 0 8}$ & $\mathbf{2 0 0 9}$ \\
\hline 1 & 90 & 96 & $\mathbf{8}$ & 76 & 72 & 72 & 76 & 77 & 96 & 88 \\
\hline 2 & 6 & 15 & 15 & 8 & 19 & 23 & 22 & 14 & 23 & 18 \\
\hline 3 & 7 & 5 & 1 & 5 & 9 & 9 & 10 & 12 & 6 & 9 \\
\hline 4 & 2 & 1 & 1 & 0 & 2 & 1 & 1 & 3 & 0 & 3 \\
\hline 5 & 0 & 0 & 1 & 0 & 0 & 0 & 2 & 2 & 0 & 0 \\
\hline 8 & 0 & 0 & 0 & 0 & 0 & 0 & 0 & 0 & 0 & 1 \\
\hline
\end{tabular}

Tabela 6. Współautorstwo publikacji w czasopiśmie Journal of Documentation

\begin{tabular}{|c|c|c|c|c|c|c|c|c|c|c|}
\hline \multirow{2}{*}{$\begin{array}{c}\text { Liczba } \\
\text { autorów }\end{array}$} & \multicolumn{10}{|c|}{ Liczba publikacji } \\
\cline { 2 - 14 } & $\mathbf{2 0 0 0}$ & $\mathbf{2 0 0 1}$ & $\mathbf{2 0 0 2}$ & $\mathbf{2 0 0 3}$ & $\mathbf{2 0 0 4}$ & $\mathbf{2 0 0 5}$ & $\mathbf{2 0 0 6}$ & $\mathbf{2 0 0 7}$ & $\mathbf{2 0 0 8}$ & $\mathbf{2 0 0 9}$ \\
\hline 1 & 66 & 94 & 81 & 58 & 46 & 71 & 51 & 40 & 45 & 58 \\
\hline 2 & 9 & 9 & 6 & 7 & 13 & 9 & 11 & 20 & 19 & 7 \\
\hline 3 & 5 & 4 & 5 & 6 & 3 & 7 & 5 & 5 & 5 & 3 \\
\hline 4 & 1 & 2 & 0 & 2 & 2 & 0 & 4 & 5 & 2 & 3 \\
\hline 5 & 0 & 0 & 0 & 0 & 0 & 0 & 0 & 0 & 0 & 2 \\
\hline 7 & 0 & 0 & 0 & 0 & 1 & 0 & 0 & 0 & 0 & 1 \\
\hline 11 & 0 & 0 & 0 & 0 & 1 & 0 & 0 & 0 & 0 & 0 \\
\hline
\end{tabular}

Tabela 7. Współautorstwo publikacji w czasopiśmie

Journal of the American Society for Information Science and Technology

\begin{tabular}{|c|c|c|c|c|c|c|c|c|c|c|}
\hline \multirow{2}{*}{$\begin{array}{c}\text { Liczba } \\
\text { autorów }\end{array}$} & \multicolumn{10}{|c|}{ Liczba publikacji } \\
\cline { 2 - 14 } & $\mathbf{2 0 0 0}$ & $\mathbf{2 0 0 1}$ & $\mathbf{2 0 0 2}$ & $\mathbf{2 0 0 3}$ & $\mathbf{2 0 0 4}$ & $\mathbf{2 0 0 5}$ & $\mathbf{2 0 0 6}$ & $\mathbf{2 0 0 7}$ & $\mathbf{2 0 0 8}$ & $\mathbf{2 0 0 9}$ \\
\hline $\mathbf{1}$ & $\mathbf{2}$ & $\mathbf{3}$ & $\mathbf{4}$ & $\mathbf{5}$ & $\mathbf{6}$ & $\mathbf{7}$ & $\mathbf{8}$ & $\mathbf{9}$ & $\mathbf{1 0}$ & $\mathbf{1 1}$ \\
\hline 1 & 99 & 85 & 81 & 76 & 69 & 65 & 94 & 105 & 92 & 93 \\
\hline 2 & 33 & 37 & 29 & 44 & 39 & 51 & 54 & 68 & 72 & 67 \\
\hline
\end{tabular}




\begin{tabular}{|c|c|c|c|c|c|c|c|c|c|c|}
\hline $\mathbf{1}$ & $\mathbf{2}$ & $\mathbf{3}$ & $\mathbf{4}$ & $\mathbf{5}$ & $\mathbf{6}$ & $\mathbf{7}$ & $\mathbf{8}$ & $\mathbf{9}$ & $\mathbf{1 0}$ & $\mathbf{1 1}$ \\
\hline 3 & 17 & 15 & 18 & 21 & 19 & 18 & 28 & 29 & 36 & 51 \\
\hline 4 & 7 & 8 & 7 & 7 & 13 & 8 & 16 & 15 & 11 & 21 \\
\hline 5 & 2 & 4 & 6 & 2 & 5 & 8 & 8 & 9 & 9 & 7 \\
\hline 6 & 2 & 0 & 3 & 0 & 3 & 1 & 1 & 5 & 6 & 4 \\
\hline 7 & 2 & 0 & 2 & 0 & 0 & 1 & 2 & 1 & 0 & 1 \\
\hline 8 & 0 & 0 & 0 & 0 & 0 & 1 & 0 & 0 & 0 & 0 \\
\hline 9 & 0 & 0 & 0 & 0 & 0 & 0 & 1 & 1 & 1 & 0 \\
\hline
\end{tabular}

Tabela 8. Współautorstwo publikacji w czasopiśmie Library and Information Science Research

\begin{tabular}{|c|c|c|c|c|c|c|c|c|c|c|}
\hline \multirow{2}{*}{$\begin{array}{c}\text { Liczba } \\
\text { autorów }\end{array}$} & \multicolumn{10}{|c|}{ Liczba publikacji } \\
\cline { 2 - 14 } & $\mathbf{2 0 0 0}$ & $\mathbf{2 0 0 1}$ & $\mathbf{2 0 0 2}$ & $\mathbf{2 0 0 3}$ & $\mathbf{2 0 0 4}$ & $\mathbf{2 0 0 5}$ & $\mathbf{2 0 0 6}$ & $\mathbf{2 0 0 7}$ & $\mathbf{2 0 0 8}$ & $\mathbf{2 0 0 9}$ \\
\hline 1 & 26 & 26 & 25 & 17 & 18 & 26 & 29 & 34 & 31 & 20 \\
\hline 2 & 13 & 7 & 7 & 13 & 19 & 19 & 17 & 14 & 19 & 16 \\
\hline 3 & 1 & 3 & 3 & 1 & 3 & 4 & 2 & 4 & 3 & 3 \\
\hline 4 & 0 & 0 & 1 & 0 & 0 & 0 & 2 & 1 & 1 & 1 \\
\hline 5 & 0 & 0 & 0 & 0 & 0 & 0 & 1 & 1 & 0 & 0 \\
\hline 6 & 0 & 1 & 0 & 0 & 0 & 0 & 0 & 0 & 0 & 0 \\
\hline 9 & 0 & 0 & 0 & 0 & 0 & 0 & 1 & 0 & 0 & 0 \\
\hline 10 & 0 & 0 & 0 & 1 & 0 & 0 & 0 & 0 & 0 & 0 \\
\hline 15 & 0 & 0 & 0 & 1 & 0 & 0 & 0 & 0 & 0 & 0 \\
\hline
\end{tabular}

Wyniki zbiorczej analizy danych ze wszystkich badanych czasopism (Tab. 9) pokazują, że zmienia się liczba artykułów jednoautorskich, malejąc w latach 2000-2004 i rosnąc w latach 2005-2009, natomiast wśród artykułów 2- i 3-autorskich wyraźnie widać niemal stałą tendencję rosnącą.

Tabela 9. Współautorstwo publikacji w czasopismach zagranicznych w latach 2000-2009

\begin{tabular}{|c|c|c|c|c|c|c|c|c|c|c|}
\hline \multirow{2}{*}{$\begin{array}{c}\text { Liczba } \\
\text { autorów }\end{array}$} & \multicolumn{10}{|c|}{ Liczba publikacji } \\
\cline { 2 - 14 } & $\mathbf{2 0 0 0}$ & $\mathbf{2 0 0 1}$ & $\mathbf{2 0 0 2}$ & $\mathbf{2 0 0 3}$ & $\mathbf{2 0 0 4}$ & $\mathbf{2 0 0 5}$ & $\mathbf{2 0 0 6}$ & $\mathbf{2 0 0 7}$ & $\mathbf{2 0 0 8}$ & $\mathbf{2 0 0 9}$ \\
\hline $\mathbf{1}$ & $\mathbf{2}$ & $\mathbf{3}$ & $\mathbf{4}$ & $\mathbf{5}$ & $\mathbf{6}$ & $\mathbf{7}$ & $\mathbf{8}$ & $\mathbf{9}$ & $\mathbf{1 0}$ & $\mathbf{1 1}$ \\
\hline 1 & 313 & 328 & 284 & 253 & 237 & 258 & 276 & 289 & 298 & 299 \\
\hline 2 & 78 & 79 & 74 & 85 & 100 & 118 & 119 & 129 & 157 & 123 \\
\hline 3 & 34 & 32 & 31 & 41 & 45 & 44 & 56 & 59 & 64 & 81 \\
\hline 4 & 12 & 13 & 11 & 13 & 19 & 10 & 25 & 25 & 17 & 32 \\
\hline 5 & 3 & 4 & 7 & 2 & 5 & 9 & 11 & 12 & 10 & 10 \\
\hline 6 & 2 & 1 & 3 & 0 & 3 & 2 & 2 & 5 & 7 & 5 \\
\hline 7 & 2 & 0 & 2 & 0 & 1 & 1 & 2 & 1 & 0 & 2 \\
\hline 8 & 0 & 0 & 0 & 0 & 0 & 1 & 0 & 0 & 0 & 1 \\
\hline 9 & 0 & 0 & 0 & 0 & 0 & 0 & 2 & 1 & 1 & 0 \\
\hline
\end{tabular}




\begin{tabular}{|c|c|c|c|c|c|c|c|c|c|c|}
\hline $\mathbf{1}$ & $\mathbf{2}$ & $\mathbf{3}$ & $\mathbf{4}$ & $\mathbf{5}$ & $\mathbf{6}$ & $\mathbf{7}$ & $\mathbf{8}$ & $\mathbf{9}$ & $\mathbf{1 0}$ & $\mathbf{1 1}$ \\
\hline 10 & 0 & 0 & 0 & 1 & 0 & 0 & 0 & 0 & 0 & 0 \\
\hline 11 & 0 & 0 & 0 & 0 & 1 & 1 & 0 & 0 & 0 & 0 \\
\hline 15 & 0 & 0 & 0 & 1 & 0 & 0 & 0 & 0 & 0 & 0 \\
\hline
\end{tabular}

Wzrost liczby publikacji wieloautorskich nie następuje wskutek zmniejszania się liczby publikacji jednoautorskich, ale wynika z przyrostu liczby artykułów publikowanych w niektórych czasopismach, zwłaszcza w Journal of the American Society for Information Science and Technology.

Tabela 10. Liczba publikacji w badanych czasopismach zagranicznych w latach 2000-2009

\begin{tabular}{|l|c|c|c|c|c|c|c|c|c|c|}
\hline \multicolumn{1}{|c|}{ Czasopismo } & 2000 & 2001 & 2002 & 2003 & 2004 & 2005 & 2006 & 2007 & 2008 & 2009 \\
\hline $\begin{array}{l}\text { International Journal } \\
\text { of Information Mana- } \\
\text { gement }\end{array}$ & 56 & 45 & 33 & 51 & 55 & 50 & 55 & 56 & 77 & 76 \\
\hline $\begin{array}{l}\text { Journal of Academic } \\
\text { Librarianship }\end{array}$ & 105 & 117 & 105 & 89 & 102 & 105 & 111 & 108 & 125 & 119 \\
\hline $\begin{array}{l}\text { Journal of Documen- } \\
\text { tation }\end{array}$ & 81 & 109 & 92 & 73 & 66 & 87 & 71 & 70 & 71 & 74 \\
\hline $\begin{array}{l}\text { Journal of the Ame- } \\
\text { rican Society for } \\
\text { Information Science } \\
\text { and Technology }\end{array}$ & 162 & 149 & 146 & 150 & 148 & 153 & 204 & 233 & 227 & 244 \\
\hline $\begin{array}{l}\text { Library and Informa- } \\
\text { tion Science Research }\end{array}$ & 40 & 37 & 36 & 33 & 40 & 49 & 52 & 54 & 54 & 40 \\
\hline Razem & 444 & 457 & 412 & 396 & 411 & 444 & 493 & 521 & 554 & 553 \\
\hline
\end{tabular}

Tendencję wzrostu liczby publikacji wieloautorskich można zaobserwować zestawiając średnią liczbę autorów przypadających na jedną publikację w poszczególnych latach. Wyniki obliczeń prezentuje tabela 11. Łącznie ze wszystkich czasopism średnia na końcu badanego okresu (2009 r.) jest większa o 0.35 od średniej z 2000 r. i wynosi 1.84. Czasopismem o największej średniej liczbie autorów na jedną publikację (1.98) za cały badany okres jest Journal of the American Society for Information Science and Technology.

Tabela 11.Średnia liczba autorów na jedną publikację w czasopismach zagranicznych w latach 2000-2009

\begin{tabular}{|c|c|c|c|c|c|c|c|c|c|c|c|}
\hline & \multicolumn{8}{|c|}{ Średnia liczba autorów na jedna publikację } \\
\cline { 2 - 12 } & 2000 & 2001 & 2002 & 2003 & 2004 & 2005 & 2006 & 2007 & 2008 & 2009 & $\begin{array}{c}\text { śr. } \\
2000- \\
2009\end{array}$ \\
\hline 1 & 2 & 3 & 4 & 5 & 6 & 7 & 8 & 9 & 10 & 11 & 12 \\
\hline $\begin{array}{l}\text { International } \\
\text { Journal of In- } \\
\text { formation } \\
\text { Management }\end{array}$ & 1.63 & 1.60 & 1.94 & 1.80 & 1.69 & 2.00 & 1.87 & 1.61 & 1.91 & 1.87 & 1.79 \\
\hline
\end{tabular}




\begin{tabular}{|l|c|c|c|c|c|c|c|c|c|c|c|}
\hline \multicolumn{1}{|c|}{$\mathbf{1}$} & $\mathbf{2}$ & $\mathbf{3}$ & $\mathbf{4}$ & $\mathbf{5}$ & $\mathbf{6}$ & $\mathbf{7}$ & $\mathbf{8}$ & $\mathbf{9}$ & $\mathbf{1 0}$ & $\mathbf{1 1}$ & $\mathbf{1 2}$ \\
\hline $\begin{array}{l}\text { Journal } \\
\text { of Academic } \\
\text { Librarianship }\end{array}$ & 1.25 & 1.24 & 1.23 & 1.20 & 1.42 & 1.42 & 1.48 & 1.51 & 1.28 & 1.44 & 1.35 \\
\hline $\begin{array}{l}\text { Journal of Do- } \\
\text { cumentation }\end{array}$ & 1.27 & 1.21 & 1.17 & 1.34 & 1.62 & 1.26 & 1.46 & 1.64 & 1.49 & 1.49 & 1.38 \\
\hline $\begin{array}{l}\text { Journal of the } \\
\text { American } \\
\text { Society for } \\
\text { Information } \\
\text { Science and } \\
\text { Technology }\end{array}$ & 1.73 & 1.72 & 1.94 & 1.77 & 2.02 & 2.05 & 2.05 & 2.06 & 2.11 & 2.17 & 1.98 \\
\hline $\begin{array}{l}\text { Library and } \\
\text { Information } \\
\text { Science Rese- } \\
\text { arch }\end{array}$ & 1.38 & 1.49 & 1.44 & 2.15 & 1.63 & 1.55 & 1.75 & 1.54 & 1.52 & 1.63 & 1.60 \\
\hline Srednia & 1.49 & 1.44 & 1.54 & 1.60 & 1.73 & 1.69 & 1.79 & 1.79 & 1.76 & 1.84 & 1.68 \\
\hline
\end{tabular}

Obserwując wzrost liczby publikacji wieloautorskich w czasopismach zagranicznych, można zastanawiać się nad przyczyną tej tendencji. Wśród hipotez można wskazać:

(1) Wzrost stopnia skomplikowania problemów badawczych.

(2) Potrzebę większych środków finansowych na badania, co może być osiągnięte głównie dzięki współpracy między instytucjami (większa szansa na uzyskanie grantu).

(3) Rozwój komunikacji elektronicznej (oprogramowanie do pracy grupowej, telekonferencje), która ułatwia nawiązywanie kontaktów i przyspiesza wymianę informacji.

(4) Dostęp do wysokospecjalistycznej aparatury badawczej, którą posiada niewiele ośrodków (w bibliologii i informatologii rzadko jednak wykorzystuje się taki sprzęt).

(5) Zwiększenie się objętości artykułów naukowych, co może być związane z pierwszą hipotezą.

(6) System promowania współpracy w nauce (czego brakuje w Polsce).

Weryfikacja pierwszych czterech hipotez oraz hipotezy szóstej wymaga osobnych badań jakościowych, których przedmiotem byliby zarówno naukowcy, którzy nawiązują współpracę, jak i naukowcy pracujący indywidualnie i niepodejmujący współpracy. Natomiast piąta hipoteza, dotycząca związku autorstwa zbiorowego z objętością publikacji, da się zweryfikować za pomocą obliczeń.

Wyniki badań pokazały zauważalny wzrost liczby artykułów o objętości 6-15 stron. Tabela 12 prezentuje wyniki ograniczone do publikacji o objętości 4-20 stron.

Tabela 12. Liczba publikacji w czasopismach zagranicznych w zależności od liczby stron

\begin{tabular}{|c|c|c|c|c|c|c|c|c|c|c|c|}
\hline \multirow{2}{*}{$\begin{array}{c}\text { Liczba } \\
\text { stron }\end{array}$} & \multicolumn{10}{|c|}{ Liczba publikacji } \\
\cline { 2 - 15 } & $\mathbf{2 0 0 0}$ & $\mathbf{2 0 0 1}$ & $\mathbf{2 0 0 2}$ & $\mathbf{2 0 0 3}$ & $\mathbf{2 0 0 4}$ & $\mathbf{2 0 0 5}$ & $\mathbf{2 0 0 6}$ & $\mathbf{2 0 0 7}$ & $\mathbf{2 0 0 8}$ & $\mathbf{2 0 0 9}$ & Suma \\
\hline $\mathbf{1}$ & $\mathbf{2}$ & $\mathbf{3}$ & $\mathbf{4}$ & $\mathbf{5}$ & $\mathbf{6}$ & $\mathbf{7}$ & $\mathbf{8}$ & $\mathbf{9}$ & $\mathbf{1 0}$ & $\mathbf{1 1}$ & $\mathbf{1 2}$ \\
\hline 4 & 19 & 18 & 21 & 27 & 21 & 26 & 24 & 19 & 6 & 18 & 199 \\
\hline 5 & 13 & 16 & 13 & 10 & 10 & 13 & 14 & 12 & 16 & 13 & 130 \\
\hline
\end{tabular}




\begin{tabular}{|c|c|c|c|c|c|c|c|c|c|c|c|}
\hline $\mathbf{1}$ & $\mathbf{2}$ & $\mathbf{3}$ & $\mathbf{4}$ & $\mathbf{5}$ & $\mathbf{6}$ & $\mathbf{7}$ & $\mathbf{8}$ & $\mathbf{9}$ & $\mathbf{1 0}$ & $\mathbf{1 1}$ & $\mathbf{1 2}$ \\
\hline 6 & 15 & 16 & 20 & 13 & 18 & 14 & 17 & 15 & 12 & 22 & 162 \\
\hline 7 & 10 & 15 & 11 & 14 & 14 & 22 & 19 & 10 & 31 & 29 & 175 \\
\hline 8 & 11 & 13 & 14 & 18 & 15 & 19 & 14 & 25 & 29 & 25 & 183 \\
\hline 9 & 20 & 17 & 10 & 16 & 16 & 15 & 21 & 19 & 41 & 37 & 212 \\
\hline 10 & 10 & 8 & 14 & 15 & 21 & 23 & 31 & 24 & 24 & 32 & 202 \\
\hline 11 & 10 & 16 & 14 & 7 & 18 & 33 & 24 & 35 & 28 & 28 & 213 \\
\hline 12 & 24 & 16 & 15 & 18 & 11 & 12 & 28 & 23 & 27 & 28 & 202 \\
\hline 13 & 14 & 16 & 21 & 22 & 9 & 25 & 31 & 33 & 30 & 20 & 221 \\
\hline 14 & 14 & 14 & 15 & 11 & 24 & 20 & 28 & 24 & 24 & 31 & 205 \\
\hline 15 & 16 & 11 & 8 & 5 & 20 & 11 & 23 & 23 & 22 & 24 & 163 \\
\hline 16 & 13 & 11 & 9 & 13 & 12 & 15 & 20 & 17 & 18 & 11 & 139 \\
\hline 17 & 8 & 7 & 7 & 10 & 7 & 12 & 10 & 13 & 10 & 9 & 93 \\
\hline 18 & 7 & 3 & 7 & 11 & 8 & 7 & 6 & 9 & 7 & 10 & 75 \\
\hline 19 & 10 & 12 & 7 & 5 & 11 & 4 & 5 & 10 & 5 & 7 & 76 \\
\hline 20 & 8 & 3 & 4 & 6 & 7 & 4 & 6 & 5 & 10 & 8 & 61 \\
\hline
\end{tabular}

Na podstawie procentowego zestawienia udziału artykułów w zależności od liczby autorów i liczby stron łatwo dostrzec związek między tymi wartościami. Dane zebrane w tabeli 13 pokazują, że im większa liczba stron, tym mniejszy udział artykułów jednoautorskich i odpowiednio rosnący udział artykułów napisanych przez 2, 3, 4, 5 i 6 autorów. Na przykład, wśród publikacji 6-stronicowych artykuły jednoautorskie stanowią 3.4\%, artykuły dwóch autorów $-4.1 \%$, trzech autorów $-2.5 \%$, czterech autorów $-3.4 \%$, pięciu autorów $-4.1 \%$, sześciu autorów - 3.3\%, natomiast wśród publikacji 12-stronicowych artykuły jednoautorskie stanowią $2.3 \%$, artykuły dwóch autorów $-6.9 \%$, artykuły trzech autorów $-8 \%$, artykuły czterech autorów $-6.8 \%$, artykuły pięciu autorów $-8.2 \%$, artykuły sześciu autorów - 10\%.

Tabela 13. Procentowy udział publikacji w czasopismach zagranicznych w zależności od liczby stron i liczby autorów

\begin{tabular}{|c|c|c|c|c|c|c|c|c|c|c|c|c|c|c|c|c|c|}
\hline 范 & \multicolumn{17}{|c|}{ Liczba stron } \\
\hline 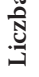 & 4 & 5 & 6 & 7 & 8 & 9 & 10 & 11 & 12 & 13 & 14 & 15 & 16 & 17 & 18 & 19 & 20 \\
\hline & \multicolumn{17}{|c|}{$\%$ publikacji } \\
\hline 1 & 5.6 & 2.9 & 3.4 & 3.2 & 2.7 & 3.0 & 2.8 & 3.0 & 2.3 & 2.4 & 2.4 & 1.4 & 1.5 & 1.2 & 0.9 & 1.0 & 1.1 \\
\hline 2 & 3.0 & 3.2 & 4.1 & 5.5 & 5.5 & 6.4 & 6.3 & 6.1 & 6.9 & 7.4 & 7.1 & 6.4 & 4.4 & 3.4 & 2.3 & 2.1 & 1.9 \\
\hline 3 & 1.4 & 2.3 & 2.5 & 4.1 & 6.6 & 7.4 & 6.8 & 9.0 & 8.0 & 8.8 & 7.2 & 5.7 & 6.8 & 2.9 & 3.1 & 2.1 & 1.2 \\
\hline 4 & 0.6 & 1.7 & 3.4 & 2.8 & 6.2 & 9.0 & 7.3 & 6.8 & 6.8 & 10.2 & 9.0 & 7.9 & 6.2 & 1.7 & 3.4 & 6.8 & 1.7 \\
\hline 5 & 0.0 & 1.4 & 4.1 & 0.0 & 4.1 & 9.6 & 8.2 & 8.2 & 8.2 & 12.3 & 8.2 & 12.3 & 5.5 & 6.8 & 2.7 & 1.4 & 0.0 \\
\hline 6 & 0.0 & 0.0 & 3.3 & 0.0 & 6.7 & 0.0 & 13.3 & 0.0 & 10.0 & 16.7 & 10.0 & 13.3 & 0.0 & 3.3 & 3.3 & 3.3 & 6.7 \\
\hline
\end{tabular}


Wzrost liczby artykułów wieloautorskich jest wyraźnie widoczny dla publikacji od 6-15-stronicowych, czyli tych, których liczba się zwiększyła (zob. wniosek z Tab. 12).

Zaprezentowane dotychczas dane pokazują, że w badanym okresie wzrosła liczba artykułów (Tab. 10), zwiększyła się liczba publikacji 6-15-stronicowych (Tab. 12) oraz że w artykułach 4-20-stronicowych można zaobserwować korelację między liczbą stron a liczbą autorów (Tab. 13). Nie znając powodów ogólnego wzrostu liczby artykułów ani powodów wzrostu liczby artykułów o danej liczbie stron, a także nie posiadając informacji na temat ogólnej liczby autorów (być może zwiększyła się liczba badaczy i stąd wzrost liczby artykułów) nie można wskazać żadnych zależności przyczynowo-skutkowych z wyjątkiem wspomnianych tendencji i korelacji. Można jednak przyjrzeć się jeszcze pewnej zależności, która mogłaby być wykorzystana w próbie weryfikacji wspomnianych hipotez $1-4$. Tabela 14 pokazuje, jak w ciągu 10 lat wzrastała średnia liczba autorów dla publikacji o tej samej liczbie stron.

Tabela 14. Średnia liczba autorów artykułów z czasopism zagranicznych w zależności od liczby stron i roku publikacji

\begin{tabular}{|c|c|c|c|c|c|c|c|c|c|c|c|}
\hline \multirow[b]{2}{*}{ 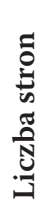 } & \multicolumn{11}{|c|}{ Średnia liczba autorów } \\
\hline & 2000 & 2001 & 2002 & 2003 & 2004 & 2005 & 2006 & 2007 & 2008 & 2009 & 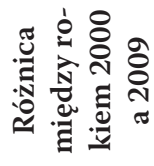 \\
\hline 4 & 1.32 & 1.39 & 1.19 & 1.19 & 1.19 & 1.19 & 1.21 & 1.26 & 1.17 & 1.39 & $5 \%$ \\
\hline 5 & 1.23 & 1.50 & 1.31 & 1.20 & 1.40 & 1.46 & 1.64 & 1.75 & 1.88 & 1.77 & $44 \%$ \\
\hline 6 & 1.60 & 1.44 & 1.70 & 1.54 & 1.89 & 1.50 & 1.41 & 1.40 & 1.83 & 1.91 & $19 \%$ \\
\hline 7 & 1.40 & 1.73 & 1.36 & 1.50 & 1.71 & 1.68 & 1.63 & 1.90 & 1.55 & 1.83 & $31 \%$ \\
\hline 8 & 1.73 & 1.92 & 2.21 & 1.72 & 2.20 & 1.74 & 2.36 & 1.76 & 2.10 & 2.00 & $16 \%$ \\
\hline 9 & 1.95 & 2.18 & 1.90 & 2.56 & 2.19 & 1.80 & 1.81 & 2.37 & 1.98 & 2.16 & $11 \%$ \\
\hline 10 & 2.00 & 2.25 & 1.64 & 2.60 & 2.19 & 1.96 & 2.10 & 2.04 & 1.88 & 2.38 & $19 \%$ \\
\hline 11 & 1.90 & 1.69 & 2.21 & 2.14 & 1.94 & 2.21 & 2.29 & 1.69 & 2.14 & 2.32 & $22 \%$ \\
\hline 12 & 1.92 & 1.88 & 1.93 & 1.89 & 2.64 & 1.83 & 2.75 & 2.43 & 2.33 & 2.21 & $15 \%$ \\
\hline 13 & 2.00 & 1.88 & 2.19 & 2.14 & 2.00 & 2.16 & 2.23 & 2.42 & 2.80 & 2.25 & $13 \%$ \\
\hline 14 & 2.43 & 2.07 & 2.07 & 2.18 & 2.29 & 2.35 & 2.18 & 1.96 & 1.79 & 2.71 & $12 \%$ \\
\hline 15 & 1.94 & 1.73 & 1.75 & 2.20 & 2.35 & 2.00 & 2.43 & 2.83 & 2.91 & 2.33 & $20 \%$ \\
\hline 16 & 1.77 & 2.09 & 2.33 & 2.00 & 2.08 & 2.87 & 2.35 & 2.12 & 2.22 & 2.45 & $38 \%$ \\
\hline 17 & 2.38 & 1.71 & 1.29 & 2.30 & 1.86 & 2.50 & 1.60 & 2.15 & 2.20 & 2.11 & $-11 \%$ \\
\hline 18 & 2.29 & 2.33 & 2.00 & 1.73 & 2.13 & 2.86 & 2.17 & 3.33 & 2.14 & 2.40 & $5 \%$ \\
\hline 19 & 2.00 & 2.17 & 2.71 & 1.80 & 2.91 & 2.75 & 2.40 & 2.10 & 2.00 & 1.86 & $-7 \%$ \\
\hline 20 & 2.00 & 2.00 & 1.75 & 1.50 & 2.29 & 1.50 & 1.17 & 2.80 & 1.30 & 2.25 & $13 \%$ \\
\hline
\end{tabular}

Porównując dane dla 2000 i 2009 r. otrzymujemy wzrost średniej liczby autorów publikacji od 5 do 44\% niemal we wszystkich artykułach o tej samej liczbie stron. Tylko dla artykułów 17 - i 19-stronicowych nastąpił spadek średniej. Widać więc, że wzrost średniej 
liczby autorów na artykuł nie może być spowodowany wyłącznie zwiększającą się objętością publikacji, ponieważ to zjawisko obserwuje się również dla tej samej liczby stron. Na przykład artykuły 15-stronicowe w 2000 r. miały średnio 1.94 autora, a w 2009 r. - 2.33, co daje $20 \%$ wzrost przy tej samej liczbie stron. Aby dowiedzieć się skąd ten przyrost, należy zweryfikować postawione wcześniej hipotezy, przeprowadzając badania jakościowe.

\section{Wykorzystanie publikacji anglojęzycznych}

Podstawą międzynarodowej współpracy, oprócz wspólnego pola badawczego, jest znajomość wspólnego języka. W zespołach wielonarodowych jest to obecnie najczęściej język angielski. Trudno obiektywnie zmierzyć poziom znajomości języka angielskiego wśród polskich bibliologów i informatologów. Jednym ze wskaźników kompetencji językowych może być liczba anglojęzycznych tekstów cytowanych w publikacjach ${ }^{4}$. Oczywiście wykorzystanie literatury obcej w dużym stopniu zależy od tematyki badawczej i z pewnością nie można wyciągać wniosków, że naukowcy, którzy nie cytują obcojęzycznych tekstów, nie znają języka obcego. W bibliologii i interdyscyplinarnej informatologii istnieje jednak wiele pól badawczych, którymi zajmują się naukowcy na całym świecie i dlatego przytoczenie danych na temat wykorzystania literatury anglojęzycznej w polskim piśmiennictwie z tego zakresu może dać przybliżony obraz stopnia posługiwania się polskich autorów językiem angielskim w celach naukowych.

Baza CYTBIN rejestruje 992 autorów artykułów, opublikowanych w polskich czasopismach z bibliologii i informatologii, z których 149 (15\%) przynajmniej raz powołało się na artykuł w anglojęzycznym czasopiśmie. W bazie znajduje się 2841 opisów cytowanych artykułów w języku polskim i 979 w języku angielskim ${ }^{5}$. Stosunek liczby cytowanych dokumentów w języku angielskim do dokumentów w języku polskim wynosi 0.34, ale należy uwzględnić fakt, iż wśród autorów cytujących są Anglicy i Amerykanie współpracujący z polskimi uczelniami, którzy z zarejestrowanych 979 cytowanych dokumentów w języku angielskim przytoczyli ok.300 z nich. Zatem wśród wszystkich cytowanych artykułów z czasopism, 24\% to publikacje anglojęzyczne.

Trudno wyobrazić sobie szeroką, efektywną współpracę międzynarodową, gdy tylko $15 \%$ polskich bibliologów i informatologów wykorzystuje w swoich pracach wyniki badań publikowanych w anglojęzycznych czasopismach naukowych. Usprawiedliwieniem tego stanu rzeczy raczej nie może być odmienność pól badawczych, gdyż jest mało prawdopodobne, aby aż $85 \%$ polskich naukowców zajmowało się tematyką o zakresie ograniczonym do zagadnień podejmowanych wyłącznie w Polsce i nie badanych na świecie przez innych naukowców. Wielce prawdopodobną przyczyną pomijania anglojęzycznej literatury w publikacjach polskich bibliologów i informatologów jest słaba znajomość języka angielskiego, ale ten problem powinien zostać dokładniej zbadany, ponieważ korzystanie ze światowego dorobku naukowego, wydaje się koniecznością nie tylko w kontekście współpracy międzynarodowej, ale także rozwoju i jakości badań naukowych w Polsce.

${ }^{4}$ Cytowania są jednym z ważnych wskaźników ukazujących recepcję tekstu. Spełniają nie tylko etyczną funkcję w nauce, ale stanowią środek komunikacji naukowej i pozwalają na ukazanie rozwoju danej dziedziny, a także jej przenikanie z innymi dyscyplinami (Marszakowa-Szajkiewicz, 1996, 11).

${ }^{5}$ Liczba cytowanych artykułów we wszystkich pozostałych językach wynosi w sumie ok.100. 


\title{
6. Podsumowanie
}

Przeprowadzone badania ukazały tendencję wzrostu liczby publikacji wieloautorskich w piśmiennictwie zagranicznym w latach 2000-2009, w których artykuły wieloautorskie stanowią 39\% ogółu publikacji. Natomiast w literaturze polskiej zaobserwowano w tym okresie stały, 9\% udział publikacji wieloautorskich. W badanych czasopismach zagranicznych regularnie pojawiają się artykuły trzech i większej liczby autorów, stanowiąc 16\% ogółu publikacji, podczas gdy w czasopismach polskich artykuły autorstwa, co najwyżej trzech osób, stanowią zaledwie $1 \%$ wszystkich publikacji.

Przedstawione wyniki obejmują publikacje z lat 2000-2009, więc należałoby podjąć kolejne badanie w celu ustalenia, czy opisany stan rzeczy, tendencje i korelacje uległy zmianie w ciągu ostatnich czterech lat (2010-2013). Być może w polskim piśmiennictwie specjalistycznym, wzorem zagranicznego, pojawiła się już tendencja wzrostu liczby publikacji wieloautorskich. Nie wiadomo jednak, jak współautorstwo wpływa na jakość badań i publikowanych prac. To osobny temat do rozważań i analiz. Równie interesującym tematem badawczym jest międzynarodowa współpraca naukowców, rozpatrywana z punktu widzenia wspólnych badań i publikacji.

\section{Bibliografia}

Drabek, A. (2007). Analiza czasopism z bibliotekoznawstwa i informacji naukowej (na podstawie bazy danych Journal Citation Reports Social Sciences Edition 1999-2004). W: E. Gondek, D. Pietruch-Reizes (red.) Studia z informacji naukowej i dyscyplin pokrewnych. Prace dedykowane Profesor Barbarze Stefaniak. Katowice: Wydaw. UŚ, 130-147.

Greene, M. (2007). The demise of the lone author. History of the Journal Nature [online] [08.04.2013], http://www.nature.com/nature/history/full/nature06243.html

Harsanyi, M. A. (1993). Multiple authors, multiple problems - bibliometrics and the study of scholarly collaboration: A literature review. Library and Information Science Research, 15, 325-354.

Marszakowa-Szajkiewicz, I. (1996). Bibliometryczna analiza wspótczesnej nauki. Katowice: Wydaw. UŚ. O'Connor, J. G. (1970). Growth of multiple authorship. DRTC Seminar, 7, 463-483.

Price, D. J. de S. (1963). Little science, big science. New York: Columbia University Press.

\section{Co-authorship of Publications in Selected Polish and International Journals in Library and Information Science}

\begin{abstract}
Purpose/thesis: The purpose of the paper is to present the results of the analysis of co-authorship in selected Polish and international library and information science (LIS) journals in the years 2000-2009. Attention is also drawn to Polish LIS scholars' command of the English language, which has an impact on their international cooperation and co-authorship.

Approach/method: The analysis was performed with the data from the CYTBIN bibliographic database and five international journals: International Journal of Information Management, Journal
\end{abstract}


of Academic Librarianship, Journal of Documentation, Journal of the American Society for Information (current title: Journal of the Association for Information Science and Technology), Science and Technology, Library and Information Science Research.

Results and conclusions: The findings show an increase trend in the number of multi-authored publications in the examined international journals published in the years 2000-2009 in which the multi-authored papers constitute $39 \%$ of all publications while in Polish journals multi-authored publications account for $9 \%$ only. In the international journals papers by three or more authors are published on a regular basis, making $16 \%$ of all publications, whereas in Polish journals papers by no more than three authors are published, accounting for $1 \%$ of all publications only.

Originality/value: The research is a quantitative analysis of co-authorship in Polish LIS journals compared to the co-authorship present in the international journals.

\section{Keywords}

Bibliometric analysis. Co-authorship. International cooperation. Library and Information Science. Poland.

Dr JACEK TOMASZCZYK jest adiunktem w Instytucie Bibliotekoznawstwa i Informacji Naukowej Uniwersytetu Ślaskiego. Prowadzi badania nad wykorzystaniem systemów terminologicznych $w$ organizacji wiedzy specjalistycznej. W kręgu jego zainteresowań leży również zarzadzanie informacja własna oraz problematyka nadmiaru informacji i jego wptywu na procesy kognitywne. Ostatnie, najważniejsze publikacje: Angielsko-polski stownik informacji naukowej i bibliotekoznawstwa. Katowice 2009; Systemy informatyczne wspomagajace zarzadzanie wiedza. Praktyka i Teoria Informacji Naukowej i Technicznej, 2010, 3, 28-35; Mapa tematów jako system reprezentacji wiedzy. W: B. Sosińska-Kalata, E. Chuchro (red.) Nauka o informacji w okresie zmian. Warszawa 2013, 389-400.

Kontakt $z$ autorem: jacek.tomaszczyk@us.edu.pl

Instytutu Bibliotekoznawstwa i Informacji Naukowej

Uniwersytet Ślaski w Katowicach

Plac Sejmu Ślaskiego 1

40-032 Katowice 